\title{
"There is no Real End" Biological Regeneration and the Resurgence of African Traditional Religion in the Contemporary World
}

\section{Elizabeth Onyedinma Ezenweke (Ph.D)}

\author{
Department of Religion \& Human Relations, \\ Nnamdi Azikiwe University, Awka, Anambra, Nigeria \\ Email: bertoivy@yahoo.com
}

Doi:10.5901/ajis.2016.v5n2p195

\begin{abstract}
It has been reported that a team of researchers did develop a mathematical model that predicts a virtually end to religious affiliation in given countries. The flawlessness of this supposition is highly doubted especially in the context of African Traditional Religion in particular and in human society too. Though the three Abrahamic religions; Judaism, Christianity and Islam use terms as "end of time(s)" and "end of days" to depict a period referred to as eschatology, do they really mean end of religion or religious affiliation? African Traditional Religion predominates cultures in Africa and have its philosophical interpretations of God, man and the universe ever before it came in contact with other cultures. In spite of the influence of Christianity, did the traditional religion of Africa die? Or, has there been a proof of the death of any religion? This paper using Charles Dinsmore theory of regeneration and other secondary sources demonstrate the rebirth of African Traditional Religion in the contemporary world. The paper therefore concludes that as far humanity is concerned, religion cum religious affiliation may at various times, decline, adapt new insights and be rebound hence, there is no real end. The paper further flaws the said prediction.
\end{abstract}

Keywords: Religion, Ends, Resurgence, Regeneration, African Traditional Religion

\section{Introduction}

The report of the prediction of the end of religion and religious affiliation in many countries at a given period by a team of researchers (Knapp, 2011) is receiving an astounding attention in the academic world, especially in the field of religion, philosophy, sociology and theology.

According to the BBC report, a team of researchers have developed a mathematical model that predicts a virtual end to religious affiliation in nine different countries. The team's mathematical model attempts to account for the interplay between the number of religious respondents and the social motives behind being one. The result, reported at the American Physical Society meeting in Dallas, US, indicates that religion will all but die out altogether in those countries. The team took census data stretching back as far as a century from countries in which the census queried religious affiliation. These countries include; Australia, Austria, Canada, the Czech Republic, Finland, Ireland, the Netherlands, New Zealand and Switzerland (Knapp, 2011).

This is an interesting supposition, and it's definitely true that religious affiliation has declined substantially in recent years in different countries all over the world. But it is important to remember that religious affiliation tends to wax and wane over time, and different social groups tend to interact with religious affiliation differently at different points. Internal and external factors such as clergy scandals, the politicization of religious belief and a rise in secularism are taking a beating on religion. Yet, will that remain true in the future? Does it conclude an end to religion and religious affiliation? The answer is certainly no.

The influx of scientific inquiry of nature appears to have a built-in bias towards predicting the extinction of religion. In the beginning of missionary activities in Africa, African Traditional religion was perceived as the direct opposite of Christianity and so, needed to be completely exterminated. This perception was based on various misconceptions, ignorance and superiority complex. At that time too, the world or what may be called the human society was divided into two types; western and non-western, civilized and primitive or logical and pre-logical. Invariably the Western perception of things was used as the yardstick to measure normality. It was under this bedrock that the early European missionaries came to evangelize Africa. Africans, therefore, were generally distinguished as a primitive set of people without a logical form of religion and so, needed to be completely eradicated and replaced. 
This background led these missionaries with the high sense of superior culture and religion, not only to bring the Christian faith, but also Western culture, at the expense of local cultures and religious traditions. On the other hand, ATR was and still inseparably linked to African cultures and worldviews. This led to what may be called a cultural conflict which is demonstrated by Achebe (1958).

It should be recalled that humans have been religious for tens of thousands, if not hundreds of thousands of years. It is endemic to our culture and our ways of thinking. That may be to a large extent partly because our natural curiosity and urge to find meaning in life leads us to it inexorably. So while religious affiliation is on the decline now, if history is any indicator, traditional religions will either adapt and embrace the technological and cultural changes of the past century, or new religions will arise to take their place. When that happens, I suspect that people's affiliations will rebound.

The findings of these researchers were based on the fact that religious affiliation has declined substantially in recent years in different countries all over the world. The flawlessness of this interesting supposition is greatly challenged in literature. It is quite obvious that though religious affiliation seems to wax and wane at various points in history, it does not mean an end to religious affiliation.

However, the above assertion is demonstrated using Charles Dinsmore theory of biological regeneration. Charles Dinsmore explored the phenomenon of biological regeneration in a book he edited in 1991 titled "A History of Regeneration Research: Milestones in the Evolution of a Science" He was influenced by earlier works on regeneration and allied studies. He made remarkable contributions in the field of biological regeneration. He carried intensive and comprehensive study of biological regeneration and left no stone unturned in the said area. This theory implies that the dwindling nature of religion and religious affiliation is consistent with the regenerative nature of many living phenomena and thus, does not indicate the end of that phenomenon. However, there seems to be insufficient literature in this standpoint hence, the need for the present study.

\section{Methodology}

Based on the above bedrock, the present study flaws the prediction of end of religion in given countries based on the observed dwindling of religious affiliation. It argues that that religious affiliation may wax and dwindle at various times but does not indicate the end. It further emphasis that the observed anomaly is in consistent with the generative nature of many phenomena. In other words, the main thrust of the paper is to apply Charles Dinsmore theory of regeneration and other some scholarly works on regenerative capacity of many living things on African Traditional religion for example, to buttress the demerits of the prediction of end of religion. Furthermore, base on sufficient evidence, to proffer and conclude that Pentecostalism of the contemporary era is a 'baptized' form of African Traditional Religion and so, the "rebirth" of or the resurface of African Traditional Religion.

This study is basically a reflective conceptual one that employs observation and experience and therefore, it is an argumentative paper. The primary source of data is complemented with literal documented evidence from varied scholars. These scholastic views also serve to validate the conceptual basis of this paper.

\section{Theorising African Traditional Religion}

In this unit, we shall mainly discuss the theoretical framework of this study and the relevance of the theory to the reemergence of ATR.

\subsection{Theoretical Framework}

The study is based on the biology theory of regeneration by Charles Dinsmore. This theory establishes a process whereby an organism has the potency to redevelop, restore or renew lost parts and even remake complete copies of itself. Thus, some organisms can re-grow lost limbs, organs, and other body parts. However, the potency and capacity to regenerate varies at different degrees among the different organisms. For instance, man's regenerative capacities are limited to hair, nails, and skin, while the liver and a few other tissues display more restricted regenerative abilities. Prometheus was doomed to regenerate his liver after it had been devoured by birds (Sundayland, 2012).

Dictionary Encyclopedia defines regeneration as the act or process of regenerating or the state of being regenerated, spiritual or moral revival or rebirth and regrowth of lost or destroyed parts or organs. However, all organisms do not have the same level of regenerative pattern. They differ markedly; some organism using their old stump, generate a totally new structure when they are cut into two while some others regenerate only amputated parts. Regeneration does 
not limit itself to only the replacement of lost parts, all forms of healing; knitting of a fractured bone and the development of tissue over a wound are themselves regeneration. Many protists like the amoeba, if cut in half, can grow back into a complete organism so long as enough of the nuclear material is undamaged. The hydra, like other simple invertebrates regenerates themselves. If cut into tiny pieces and mixed up, the pieces can reorganize themselves and grow back into a complete organism. On the other hand, flatworms, if chopped up into fine pieces, each piece has the potency to regenerate into an entire organism from only a small mass of cells. Starfish, which are echinoderms, can develop entirely new body from their central section and a single arm. Newts and salamanders can regenerate lost legs and parts of eyes, but many other amphibians such as frogs and toads cannot. Research has shown that if about 75 percent of the human liver is removed, the remaining 25 percent can regenerate into a functional organ. Regeneration in this case takes the form of the enlargement of the remaining structures rather than the re-creation of the lost ones.

In a nut shell, four mechanisms for tissue regeneration in animals can be distinguished as follows; the reorganization of existing cells (as in the hydra), the differentiation of stored stem cells into the specific tissues needed (as in the salamander), the dedifferentiation of neighboring tissue cells and their subsequent regrowth as cells of the needed type (as in plants as well as certain animals like the salamander) and the compensatory growth of the surviving cells of the specific tissue (as in the human liver) (Dictionary Encyclopedia).

The theory of regeneration has been corroborated by many scholars. For instance, Goss (2016) stated that many organisms replace or restore lost or amputated body parts though in different degrees. While some grow a new structure on the stump of the old one others may dramatically replace substantial portions of themselves when they have been cut in two or often too, may grow organs or appendages that have been lost. He further added that the motile, hairlike cilia and flagella of single-celled organisms are capable of regenerating themselves within an hour or two after amputation. He concluded that Protists and plants, invertebrates and vertebrates of various kinds regenerate

Sundayland (2009) earlier averred that regeneration is a fascinating phenomenon whereby many organisms can regenerate lost parts and even remake complete copies of themselves but unfortunately, our regenerative capacities are limited to hair, nails, and skin, while the liver and a few other tissues display more restricted regenerative abilities. However, recent studies confirm biological regeneration and that some animals like freshwater planarians, some annelids and earthworms can even regenerate a whole brain (Plytycy, 2015; Cebria, 2015)

Ozhan and Weidinger (2015) reiterated that that the capacity to repair damaged tissues varies among vertebrates. For instance, the adult teleost fish and amphibians can regenerate heart tissue, but human beings cannot. However, heart regeneration is possible in neonatal mice, but this ability is lost within 7 days after birth. In zebra fish and neonatal mice, lost cardiomyocytes are regenerated via proliferation of spared, differentiated cardiomyocytes.

Wikipedia (2016) documented that every species is capable of regeneration, from bacteria to humans, that regeneration can either be complete or partial and at its elementary level, regeneration is mediated by the molecular processes of gene regulation. Qi (2016) added that adult stem cells that reside in particular types of tissues are responsible for tissue homeostasis and regeneration. Cellular functions of adult stem cells are intricately related to the gene expression programme

Conclusively therefore, biological regeneration is a process by which some organisms replace or restore lost or amputated body parts. Organisms differ markedly in their ability to regenerate parts. Some grow a new structure on the stump of the old one. By such regeneration whole organisms may dramatically replace substantial portions of themselves when they have been cut in two, or may grow organs or appendages that have been lost. Not all living things regenerate parts in this manner, however. The stump of an amputated structure may simply heal over without replacement. This wound healing is itself a kind of regeneration at the tissue level of organization: a cut surface heals over, a bone fracture knits, and cells replace themselves as the need arises. Regeneration is thus, one aspect of the general process of growth, is a primary attribute of all living systems. Without it there could be no life, for the very maintenance of an organism depends upon the incessant turnover by which all tissues and organs constantly renew themselves. ((Nyquist, 1932).

Regeneration as a phenomenon has some properties which include;

a) Not all organisms regenerate in the same way.

b) Sometimes the part that grows back is not the same as that which was lost.

c) Often, regeneration may be induced without having lost anything at all.

d) Sometimes that which is regenerated is very different from the original.

e) Many protests like the amoeba that have been cut in half can grow back into a complete organism so long as enough of the nuclear material is undamaged.

f) Regeneration is not of the whole body but of parts or, in some cases, nearly the entire body of an organism, 
implying the existence of at least, a remnant.

g) The capacity for regeneration varies widely in animals, with some able to regenerate whole limbs and others not, but the capacity is reduced significantly in more complex animals.

\subsubsection{Regeneration, Reproduction and Religion: A Relationship.}

Regeneration and reproduction in organisms share some common features. Plants and often lower animals reproduce through a process whereby a whole new organism is produced from a fraction of parent organism. For instance; a new plant may grow from a cut portion of another plant, some worms reproduce by splitting in two, each half growing into what was cut off, when a reasonable percent of some human organs such as; liver, kidney, pancreas, thyroid and adrenal glands are removed, the remaining fraction has the potency to enlarge to a mass equivalent to the original organ. The missing lobes of the liver for instance, are not usually replaced but the residual ones grow as large as necessary in order to restore the original function of the organ and finally, reproduction is achieved sexually by the union of an egg and sperm. In this case, an entire organism develops from a single cell, the fertilized egg, or zygote. This common reproductive features of organisms that reproduce sexually, testifies to the universality of regenerative processes.

The incident of regeneration is very much experienced in religion and religious matters. By implication, religion as a whole and the practices of religion do not actually fade away permanently but may grow dim, rejuvenate and redevelop. This is widely noticed in many aspects of religious life. In Christianity for instance, many bible passages demonstrate the regenerative nature of man. Few examples include; ... and I shall give them one heart, and shall put a new spirit within them. And I shall take the heart of stone out of their flesh and give them a heart of flesh (Ezek. 11:19), Jesus answered and said to him, "Truly, truly, I say to you, unless one is born again, he cannot see the kingdom of God (John 3:3) and therefore if any man is in Christ, he is a new creature; the old things passed away; behold, new things have come.( 2 Cor. 5:17).

In the context of this work, we shall limit have a discussion on the dwindle and resurgent phases of African traditional religion to buttress our point that there is no real end, rather, the end is the beginning as shown by the reemergence of African traditional religion.We shall demonstrate the above assertion with a glance at a brief history of African traditional religion and African Christianity as typified in the story of Umofia in Things Fall apart by Chinua Achebe.

\subsection{Relevance of Regenerative Theory to the Reemergence of ATR}

We shall start the discussion on the relevance of theory of regeneration to the death and resurface of African Traditional Religion by tracing the history of Christianity through its arrival in Africa, its planting, success and conflicts to the emergence of Pentecostalism to the reemergence of African traditional religion. This will reveal that African Traditional Religion which had been assumed to have been extinct has ever been alive. As it passes through the passage of life, it experiences growing and dwindling forces. So may have at a point in time grew dim but at other point in time waxed strong just like any other living matter. Christianity as we all know emerged from Judaism, the religion of the Jews and a class of indigenous religion like African traditional religion. The coming of Christianity seemed to diminish Judaism but did not extinct it. One may say that the copy of Christianity which the early Christians practiced at Antioch that gave them the name is not the same at the present and yet, that does not mean the end of Christianity.

African traditional religion thus, refers to the entire system of belief of the Africans before it came in contact with external influence. It is the indigenous religion of the Africans as conditioned by the geographical, social, economic and political factors of Africa. This appreciates the fact that ATR belongs to the class of indigenous religions and as such, covers thousands of small scale societies who have distinct languages, kinship systems, mythologies, ancestral memories, and homelands. These different societies comprise more than 200 million people throughout the planet today. Since these societies are extremely diverse, any general remark may look like imposing ideas and concepts on them. However, the core properties of religion are shared by all these seemingly distinct societies.

For Africa therefore, the role of traditional religion in determining the modus vivendi has been vital. African cultures are known for their religious orientation. In fact, African cultures are religious cultures. It is not possible to study African culture in isolation from religion. Religion permeates the ideal African from cradle to grave. African traditional religion, therefore, comes into play in the shaping of the African's future and has aided and sustained African civilization.

We may recall that every society, including the most developed society was once at their traditional setting. African Traditional religion is grouped under the indigenous religions, just as Judaism - a replica of ATR, is the traditional religion 
of the Jews. The birth of Jesus Christ and consequently, Christianity, did not result to the death of Judaism. It may have caused it to grow dim and eventually regenerate fully. Jesus even made it explicitly clear that he did not come to abolish the law, that is, Judaism.

Taking this as a point of departure, African Traditional Religion like any other indigenous religion did not exist in isolation without communicating with other cultures. As nature has it, in socialization, cultures must surely meet with the unavoidable consequence of diffusion and assimilation. Basically, once diffused, the antithesis must be born which is neither fully the parents stock. Likewise, African Tradition Religion at a point in history came in contact with Christianity. We shall summarize the incident of this coming together of the two cultures with a borrow of ideas from the famous 'Things Fall Apart by Chinua Achebe (1958). We shall use the People of Umuofia to symbolize the entire African race to demonstrate the birth, rejection and eventual acceptance of Christianity in African soil and how it grew, waxed, dimmed and rebounded into African Tradition Religion.

The famous Chinua Achebe, the author of "Things Fall Apart" carefully articulated as part of his work, the coming of a new religious culture into Africa, its early rejection and crises and its eventual success in African soil. The depth of penetration of this new religion and culture in Africa however remains questionable.Chapter sixteen of the said book articulated the coming of the Christian missionaries in Umuofia. We see the arrival of Christianity into a sedate rural community. They were initial clashes and mistakes; the people were not willing listeners and the missionaries were not imaginative gospellers, worsen by their arrogant superiority complex and inability to appreciate anything good in the tradition and custom of the people. Achebe (1958) summarized that:

\begin{abstract}
The missionaries begin to win converts because of their victory over the evil forest. The clansmen interpret this to mean that 'the white man's fetish has unbelievable power'. ... Okonkwo feels humiliated that his son, of all sons, joins the missionaries... He regrets the truth in the saying that 'living fire begets cold, impotent ash'. Okonkwo returns to a fastchanging Umuofia. Not only the low-born and outcasts but even a titled man, Ogbuefi Ugonna, has joined the Christians. The white man has also brought a government and a system of running it. Christianity, school, trading, and government reinforce each other and combine to undo the old order. 'What is it that has happened to our people' asks Okonkwo, 'why have they lost the power to fight?' And he resolves on behalf of the clan, 'We must fight these men and drive them from the land'. But he is now a stranger in the clan and his voice is a lone voice. Obierika understands the new changes in contrast to Okonkwo's way of approach. It is easy to drive back two white men but what happens when a white has a soildiers, messengers and 'Christians among us to fight for him'? He is very clever and 'he has put a knife on the things that held us together.'He will cut deeper and deeper and the clan will fall further apart.... Okonkwo mourned for the clan, which he saw breaking up and falling apart and he mourned for the war-like men of Umuofia, who had unaccountably become soft like women. (Pp.152 - 154).
\end{abstract}

Finally, it was Okonkwo's zeal to draw the last strength to lift himself and his clan above what he saw as degradation eventually led to his shameful death by suicide. Ironically, it was the strangers Okonkwo fought and died opposing were the only people who brought him down and buried him (Achebe, 1958). Inevitably, the powerful forces of change are like the force of a running stream that must take its course without being hindered. This may be seen as the defeat and end of ATR but was it actually an end?

\title{
3.2.1 The success of Christianity in Igbo land and its splinter groups
}

The defeat of the religion and total way of life of the people of Umuofia symbolically represent what seems to be the defeat of African traditional religion and culture in Africa. But was it a total defeat? The answer is obvious- there were remnants. However, there was a massive dwindle of the traditional religion and 'successful' implantation of Christianity and western culture. Christianity is embraced by the majority of the population in most African states. There has been tremendous growth of Christians in Africa, coupled by a relative decline in adherence to traditional African religions. At a point in history, Christianity became one of the two most widely practiced religions in Africa. The company of those who believed were of one heart and soul and lived a Chris-like life. This copy of Christianity was the one that was planted in Africa but how long did this copy of Christianity last in Africa? The remnants of African Traditional Religion continued to regenerate to a point of influencing Christian practices thus, Ezenweke (2010) observed that:

Despite the influence of Christianity, despite the attempt to interpret the world in naturalistic terms without recourse to the supernatural and occult forces by the contemporary world, the daily lives of many Africans are still being influenced by their cultural belief system. It has thus been observed that Christian faith among the African Christians in general and Igbo Christians in particular is very shallow. It has not penetrated beyond skin deep. (p.25) 
For instance, as far back as 1937 Leith-Rose as quoted by Afigbo (1980) lamented that:

\begin{abstract}
With no strain or conflict, the modern Igbo can attend communion and believe in medicine; keep a church wife and several native marriage wives, tie up preciously in the same corner of a handkerchief his rosary and the shaped bit of iron for juju made for him by an Awka blacksmith.... Many still consult fortune-tellers when they want to embark on a project. The same is true when a well-thought project flops or there is sudden death or happening that seems otherwise uncounted for (p.19).
\end{abstract}

Under this bedrock, in the early 1900s, some Christians got disenchanted with the lukewarm attitudes of members of the church or of their mainline denomination and desired for a renewal of and/or fanning into flame the gift of the Holy spirit received at baptism and ignited at the feast of Pentecost. This generated an outbreak of a movement within Christendom that is known as the Pentecostal movement.

Specifically, it started in 1901 under an acknowledged founder, C.F. Parham of Anglican Communion, with the instrumentality of his college students in Kansas, USA. In 1906, the fire of this new outbreak of Pentecostalism was extended to Azusa Street through the effort of William Seymour a black minister. (Nwaobi,1993).

Through organized revivals, hundreds and thousands of people began to join. In short with this outbreak of $20^{\text {th }}$ century Pentecostalism, it was on record that many people received spiritual power to go on mission. Thus, through the activities of many individuals, Christianity began to spread more than ever. For instance, Florence Crawford took the Pentecostal gospel to the Northwest (of USA) in her Apostolic Faith Movement. Rev. William Durham of Chicago went on mission to Los Angeles and beyond. T. B. Barrett, a Norwegian Methodist has been credited with taking Pentecostal movement to Sweden, Norway, Denmark, Germany, France and England (Falaiye, 2005).

\title{
3.2.2 The Emergence of Pentecostal Movement in Africa vis-a-vis Nigeria and Factors for its Success
}

The commencement of Pentecostalism in Africa can be traced to the effort of a woman, the wife of a Methodist preacher, John Graham Lake who had an experience of being miraculously healed of Tuberculosis by Dowie, the founder of a religious community called "Zion City" near Chicago, Illinois. In 1908, Lake led a team of missionaries to Johannesburg in South Africa and from there; Pentecostalism was spread to other parts of Africa (Obineche, 2004; Falaiye, 2007). In Nigeria, it dates back to 1930 at llesa, Osun State through the activities of Babalola of the Christ Apostolic Church and one of his evangelists called Orekoya who raised a dead woman, Alice Abeo, also in 1930. Babalola stood out among his contemporaries by the unequalled charismatic display he had in healing the sick, exorcism, deliverance from the power of darkness and especially raising a dead person (Oguejiofor, 2007; Falaiye, 2007).

It is seemingly, generally believed that the success of Pentecostal missions in Africa, Nigeria inclusive is the fact that many of the basic tenets of Pentecostalism are very much consistent with the African Traditional religious world view. As early stated, scholars share same view regarding the inclination of African Christians to their traditional world view.

At this point, we shall discuss the major argument of this study by comparing the basic tenets of Pentecostalism and African Traditional Religion with a view to ascertain their relatedness and use it therefore as a platform for the establishment of the major arguments of this study namely; Pentecostalism as the rebirth of African Traditional Religion and the irrationality of the prediction of the end of religion. This is so because, if Pentecostalism shares same tenets of African Traditional religion and so, the new form or rebirth of African Traditional Religion, the prediction of the end of religion because it grew dim at a point in history is irrational.

\section{Discussion}

As has earlier established, we shall discuss the remaining part of this paper to cover some basic tenets of African Traditional Religion and Pentecostalism, Pentecostalism as a new form of African Traditional Religion and the irrationality of the prediction of the end of religion.

As been earlier stated, African traditional religion refers to the entire primary and indigenous system of belief of the Africans before it came in contact with external influence. It is the indigenous religion of the Africans as conditioned by her worldview. However, the African world view is a multifaceted one that may not be sufficiently discussed within the context of this paper. Thus, the aspects directly required in the context of this work will be mentioned. These include; Igbo belief system, the central acceptability of occult and exorcism and the quest for healing.

In the first place, many African communities believe in many gods. Apart from the belief in the Supreme Being, there is a strong belief in other spiritual forces (Quarcoopome, 1987 and Ugwu \& Ugwueye, 2004). Basden (1966) 
remarked that 'scattered here and there throughout the Igbo community more particularly on the Eastern side of the Niger are certain local deities alleged to possess supernatural powers' (p.66). Ogbajie (1995) echoed that:

Categories of being in lgbo invisible world are many. Different powers are called up in different situations... The world of an Igbo man cannot be completely understood without his conception of magical or mystical forces, which the Igboman calls "Ogwu". Simply put, "ogwu "is a force of vital energy or mystical power that is employed for medical, magical, sorcery and witchcraft purposes. (p. 56).

Secondly, Africans, especially the Igbos, believe in the existence of various phenomena supposedly experienced by some people, which are not in line with western science. These phenomena cannot be comprehended by human understanding and so, unexplainable by the known forces of nature. It is deeply believed too, that some Africans possess certain powers that cannot be tested nor proved under the principles of scientific verification to manipulate these forces.

There is no doubt that Africans believe in the existence of supernatural powers ever before the pre- colonial era and it served them. Many ill health such as mental problems are often cured through means that cannot be verified. The world of an Igbo man cannot be completely discussed exclusive of his conception of magical or mystical forces, that is, a force of vital energy or mystical power, which is engaged for many purposes such as for medical, magical, sorcery and for witchcraft (Ogbajie, 1995).

For an Igbo man, it is believed that some human beings are able to do certain things which are extraordinary with spiritual assistance (Nwala, 1985). Senghor as cited by Ogugua (2005) accentuated that:

The Igbo people believe too that the spirit can strengthen the life force of the living, or else, why the crave to have male issue who will perform this unique function of strengthening the life forces of the people through prayer and sacrifices. (p. 71).

Thirdly, the Igbo traditional community like many other African communities, places a heavy accent on human life and its preservation. Human life is therefore, the prime and highest value. All man's effort is geared towards its maintenance. We may see this in the names they bear: 'Ndubuisi' (Life is of supreme importance) and 'Nduka' (life is greater) but to mention a few. (Madu,2004).

It is important to say here that 'ndu' (life) to an Igbo encompasses both the dynamic quality of material and human existence. Thus, death is only a dissolution of the flesh as the spirit enters a separate existence maintaining the ndu' in another form of existence. However, the state and quality of life on earth determines that state of life in the underworld (Mbiti, 1970; Ugwu \& Ugwueye, 2004). Health in other words, is far more social than biological (Onuwa, 1990).

Health for the Igbo man means a harmonious existence between the different spheres of the cosmic other in which man is a member (Madu, 2004). As earlier stated in this work, a full perception of human health involves the acquisition of the highest possible forces and energies, capable of attaining the greatest possible spiritual and physical development of man. Proper health is shown, only when one has attained full realization and actualization of himself, has acquired and can manipulate all possible forces for the accomplishment of the goal for which he was created (Onunwa, 1990).

Therefore, African communities, the Igbos inclusive, are health-oriented communities and those rituals for healing and protection from diseases and evil spirits remain prominent features of African Traditional Religion. An average Igbo man is willing to give up all he has to safeguard his health. This may account for the fact that at every sign of ill-health, efforts must be directed toward finding out the cause especially in Igbo land where nothing happens without a cause. Mbiti (1970) earlier noted that:

African people feel and believe that all the various ills, misfortunes, sickness, accidents, tragedies, sorrows, dangers and unhappy mysteries, which they encounter and experience, are caused by the use of these mystical powers in the hands of a sorcerer, witch or wizard. Nothing harmful happens by chance, someone causes everything by use of mystical power. (p. 200).

On the other hand, healing is one of, if not, the most vital aspect of Pentecostalism and this has been noted to be its powerful instrument for growth, especially in Igbo land where economic meltdown and poor health conditions compounded by illiteracy seem to be greatly witnessed. A major attraction for Pentecostalism has therefore, been its emphasis on healing. Some argue that the traditional African healers used herbs and other natural remedies as well as employing spiritual or supernatural forces in their healing process while the Pentecostals employ spiritual or supernatural practices but recently, it has also been observed that reasonable number of Pentecostal pastor also use herbs and other dietary stuff for healing. 
Again, the acknowledgement of the influence of evil spirits and the appeasement of such spirits for protection are some of the most prominent feature of the Pentecostal churches which resonates well with the tenets of ATR. African Pentecostal dramatically enacted the convictions that healing and spirituality are together as against the rationalistic western form of Christianity, which has unwittingly separated healing from religion. The stand of the African Pentecostals as herein indicated resonated well with the popular beliefs of African people (Cox, 1996).

However, Pentecostalism came along stressing that we can expect and experience miracles today, of the same nature as the miracles of the Biblical days. Since in many religions of the world, and especially in African religions, the "man of God" has power to heal the sick and ward off evil spirits and sorcery, it was a natural thing to embrace Pentecostalism which believes also in supernatural healing (Hildebrandt, 1981; Ndiokwere, 1998).

Saayman (1993) also observed that "The Pentecostal understanding of preaching of the word in evangelism was that signs and wonders should accompany it, and divine healing in particular was an indispensable part of Pentecostal evangelistic methodology". (p.46). No wonder, the prevalence of oracles, sorcerers, witches, wizards and medicine men in Igbo land has no date of origin. They were in use even before the advent of western civilization (Mbefo, 2001).

As it has been noted that the growth in the Church in the world at large, Nigeria inclusive, has always been with a difference where ministers who are charismatic are involved who have been identified with working of miracles, and claim to possess power to heal 'by the divine intervention of God' (Falaiyi, 2007). We are quite aware that even in Igbo cosmology, a god that fails to satisfy the desires of the people is replaced with a more powerful one.

More so, as earlier noted, Christianity emerged from Judaism, though may have caused Judaism to wane but certainly, did not extinct it. Invariably, Christianity flourished and has records of waxing and waning. One may say that the copy of Christianity which the early Christians practiced at Antioch that gave them the name is not the same that is practiced at the present and yet, that does not mean the end of Christianity. Therefore, a look from indigenous religion through Christianity to Pentecostalism and back to the indigenous worldview justifies that there is no real end.

The study finds out therefore that there is no real end to religion or religious affiliation as evident on the history and changing nature of ATR and Christianity. This invariably faults the prediction of the end of religion and religious affiliation in many countries. It further justifies that Pentecostalism in Africa is a new form of African Traditional religion and so, the reemergence of ATR

The findings of this study is in consistent with the views of many scholars that Pentecostalism is adapted to the African worldview with its strong emphasis on spirit world beliefs, deriving its coloring from the texture of the African soil (Kalu, 2008; Lloyd, 2015; Aderibigbe \& Medine, 2015). Scholars from diverse disciplines often refer to the nature of the modern day Pentecostalism in Africa as the "third wave" of Christianity in Africa (Meyer 2004; Robbins, 2004), in which African ministers took the lead in melding established Christian doctrine with local belief. This syncretistic form of Christianity seems uniquely suited to the African situation (Maxwell 1998).

There are echoed voices that Pentecostalism adopted an African style of worship and liturgy (Anderson 2004) and heavily relies on African Traditional Religion with its dominant beliefs and practices. (Mbiti, 1999). It has been categorically stated that a clear examination of modern era Pentecostals testifies that ATR IAIR (African Indigenous Religions) that seemed to have dwindle is resurfaced (Adamo, 2011). Anderson succintly stated that one of the outstanding features of African Pentecostals is their religious creativity and spontaneously indigenous character and that African Pentecostalism is in constant interaction with the African spirit world (Anderson, 2000).

\section{Implications and Conclusion}

There is no real end to life; the end of a life is the beginning of another life. Religion and religious affiliation will live as long as human beings live. It may change its nature but the basic tenets continue to exist. The prediction of the death of religion in a given period is what may be referred to as historians being ahead of time (Speel, 2007). This paper therefore, flaws the preposition that predicts a virtually end to religious affiliation in given countries.

Though the Abrahamic religions use terms as "end time(s)" and "end of days" to depict a period referred to as eschatology, they do not really mean end of religion or religious affiliation. Religion and religious affiliations may at various times, decline, adapt new insights and be rebound. In other words, what seems to be an end may be a gate way to a new beginning. Hence, this paper using Charles Dinsmore theory of regeneration demonstrates the resurfacing of African Traditional Religion in the contemporary world into what is seen as Pentecostalism; thus, Pentecostalism is a rebirth of African Traditional Religion.

This has a great lesson for the contemporary people of Africa in particular and Igbo people in particular who are notoriously religious people. Invariably, life has no end; death which seems to be the end of life is actually the gate to 
another life and the quality of the second phase of life is determined by the quality of life lived in the first phase. Life should therefore be morally lived. This paper therefore calls for an examined life and total adherence to moral values and virtues.

\section{References}

Achebe, C. (1958). Things fall apart. London: Heinemann.

Adamo, D. T. Christianity and the African traditional religion(s): The postcolonial round of engagement, Verbum et Ecclesia, vol.32(1) online

Aderibigbe, I. S. and Medine , C. M. J. (2015). Contemporary Perspectives on Religions in Africa and the African Diaspora, US: Palgrave Macmillan

Afigbo, E. A. (1980). An outline of Igbo history. Owerri: Rada.

Anderson, A. (2000). Evangelism and the growth of Pentecostalism in Africa. London: University of Birmingham.

Barrett, D. (2001). The world wide Holy Spirit renewal. In V. Synan (Ed.). The century of Holy Spirit: 100 years of Pentecostal and charismatic renewal, 1901-2001 (pp. 383-389). Tennessee: Thomas Nelson.

Basden, G. (1966). Among the Ibos of Nigeria. London: Frank Cass.

Cebria, Francesc, (2015), Arm regeneration in cuttlefish. (online)Available: http://gravator.com/schmidtea. (June 23, 2016)

Cox, H. (1996). Fire from heaven: The rise of Pentecostal spirituality and the reshaping of religion in the twenty first century. London: Cass ell.

Dinsmore, Charles E. (1995). BioScience. Vol. 45, No. 7 (Jul. - Aug., 1995), pp. 484-492. USA: University of Califonia press.

Dictionary Encyclopedia (2012). (online)Available: http://www.britannica.com/EBchecked/topic/495880/regeneration. (May 09, 2013).

Ezenweke, E. O. (2010). Occult and Paranormal in Pentecostal Mission: Implications for Social Cohesion in many Igbo communities. Unizik Journal of Arts and Humanities. Vol 2 (2). Pp 20-39.

Falaiye, E. A. (2007). Pentecostalism in the light of Acts chapter 1 verse 8. In A.G.Nnamani (Ed.). The new religious movement: Pentecostalism in perspective. (pp. 29 - 44). Benin City: Ava.

Goss, Richard, Johnson, (2016). Regeneration. In Encyclopædia Britannica. (online) Available: http://www.britannica.com/science/regeneration-biology. (June 23, 2016.

Hildebrandt, J. (1981). History of the church in Africa. Ghana: African Christian.

Kalu, O. (2008). African Pentecostalism. New York: Oxford University press.

Knapp, Alex (2011). Researchers Predict the End of Religion. (online) Available:. http://www.forbes.com/sites/alexknapp/2011/03/22/researchers-predict-the-end-of- religion/ (May 09, 2013).

Lloyd, J. (2015). Pentecostal Doctrines, Beliefs, Practices and African Traditional Religion, Online: Augustine Research Fellowship.

Madu, J.E.(2004). Honest to African cultural heritage. Onitsha: Coskan

Maxwell, D. (1998). Delivered from the Spirit of Poverty: Pentecostalism, Prosperity and Modernity in Zimbabwe. Journal of Religion in Africa, vol. 28, (3), pp.350-373.

Mbefo, L.N. (2001). The true Africa: Impulses for-affirmation. Onitsha: Spiritan.

Mbiti J. S (1970). African Religions and Philosophy. New York: Double day.

Mbiti, S. J. (1999). African Philosophy. Norfolk:Biddles

Meyer, B. (2004). Christianity in Africa: From African Independent to Pentecostal-Charismatic Churches. Annual Review of Anthropology, vol. 33, 447-74.

Ndiokwere, N. I. (1998). Search for greener pastures: Igbo and African experiences. U.S.A: Morris

Ndiokwere, N. I. (1998). The third millennium church. Nebraska: Morris.

Nwala, T. U. (1985). Igbo Philosophy. Nigeria: Lantern.

Nwaobi, P. O. (1993). Charismatics and the church: A historical survey. Nigeria: Shanssu.

Nyqueist, H. (1932). Theory of regeneration. Bell htts://scholar.google.com/scholar?q=theory+of+regeneration+by+nyquist\&hl=en\&as

system technical journal,

Obineche, J. O. (2004). Charismatic revolution: A challenge to orthodoxy. Owerri: Alphabet.

Ogbajie, C. (1995). The Impact of Christianity on the Igbo religion and culture. Umuahia: Ark.

Oguejiofor,J. O. (2007). Pitfalls in our Pentecostalism: A presidential address. In A.G. Nnamani (Eds). The new religious movement: Pentecostalism in perspective (pp.1-10). Benin City: Ava.

Ogugua, P. I. (2005).Understanding deities in Igbo-African worldview: A religio-hilosophical perspectives. In M. Dukor (Ed.). AnInterdisciplinary,International Journal of Concerned African Philosophers, 2, 64 - 91.

Onunwa, U. (1990). Studies in Igbo Traditional religions. Obosi: Pacific.

Ozhan, G. \& Weidinger G. (2015).Wnt/B-Catenin signaling in heart regeneration, in Cell regeneration journal.(online) Available: http://cellregenerationjournal.biomedcentral.com (June 23, 2016).

Plytycz, B. (2015). Reports on the role that the immune system may play in the regeneration of the brain in the earthworm, in Dendrobaena veneta (online) Available: http://www.ncbi.nlm.nih.gov/pubmed/25863277 (June 23, 2016).

Qi, Huayu, (2016).Cell Regeneration: RNA-binding proteins in mouse male germline stem cells: a mammalian perspective.(online) Available: http://cellregenerationjournal.biomedcentral.com/articles.10.1186/s13619-015-0022-y/ (June 23, 2016) 
Quarcoopome, T.N.O. (1987).West African Traditional Religion. Ibadan: African University.

Ray, Benjamin (1999). African Religions, Symbol and Community. Ithaca: Prentice- Hall.

Robbins, J. (2004). The Globalization of Pentecostal and Charismatic Christianity. Annual Review of Anthropology, vol. 33, pp.117-43.

Saayman,W.A.(1993). Some reflections on the Development of Pentecostal Mission model on South Africa. Missionalia.

Speel, C. J. (2007). Historian ahead of his time, Christianity, Today Magazine, February.

Sunderland, Mary E, (2012). Regeneration.(online) Available: http://hdl.handle.net/10776/1681. regeneration http://www.britannica.com/EBchecked/topic/495880/regeneration. (May 08,2013).

Sundayland, Mary E. (2009). The Embryo Project Encyclopedia:Recording and contextualizing the science of embryos, development, and reproduction.(online) Available: https://embryo.asu.edu/pages/regeneration (June23, 2016).

Ugwu, C.O.T. \& Ugwueye, L.K. (2004). African Traditional Religion: a prolegomenon. Lagos: Merit.

Wikipedia, the free encyclopedia (n.a). Christianity in Africa.(Online) Available: from http://en.wikipedia.org/w/index.php?title=Christianity_in_Africa\&oldid=553317900. (May 09, 2013)

Wikipedia, the free encyclopedia (2016). Regeneration (biology).(online). https://en.wikipedia.org/wiki/Regeneration_\%28biology\%29 (June 23, 2016). 